\title{
DWARF FAUNAS
}

\section{PROFESSOR HERVEY W. SHIMER \\ Massachusetts Institute of Technology}

Faunas in which all the individuals are uniformly so small as to be notable for this reason are common both in recent and past times. Such dwarf faunas may be merely an association of normally small species; or they may be individuals much smaller than the normal size for that species, prevented for some reason from attaining full size.

The following is an attempt to summarize some of the principal recent and dwarf faunas with the probable causes producing them. It is confined to invertebrate, water-living faunas. The article is primarily a summary of such literature as chanced to be seen; that very much of importance was overlooked is undoubtedly true, but it is thought that the major causes of dwarfing are here noted.

The first part of the article is a discussion of the chief agencies of dwarfing using recent examples as illustrations; the second part considers a few fossil examples of dwarf faunas with their probable causes.

The following are the chief agencies of dwarfing as noted in recent and fossil faunas:

1. A change in the normal chemical content of the water.

(a) Due to a freshening of the sea water.

(b) Due to a concentration of the salt, iron, etc.

(c) Due to an increase in $\mathrm{H}_{2} \mathrm{~S}$ and other gases.

2. Presence of mud and other mechanical impurities in the water.

3. A floating habitat.

4. Variations in temperature.

5. Extremes in depth of water. 
1. A Change in the Normal Chemical Content of the Water.-Any change in the environment of an animal which is away from that best suited to its highest development tends to its deterioration. If a species develops best in normal sea water, then an increase or decrease in the chemical content of the water should be detrimental to the animal, and this detriment should be expressed in the shell, since, as shown by Hyatt and others, there is the most intimate relation betwen the soft and the hard parts of an animal, the least injury in the soft parts being immediately expressed in the growing shell. This expression will usually take the form of a dwarfing in size, thinning and smoothing of the shell $\mathrm{or}^{\circ}$ development of bizarre form.

The possible changes in the normal chemical content of the water are exceedingly numerous and all doubtless affect the animal to a greater or less degree. The following appear to be some of the more important of such changes which produce a dwarfing effect.

(a) A Change due to Freshening of the Water.-That many forms of animals find fresh water detrimental to them appears to be indicated by the fact that at present whole groups are excluded from it, as the Echinodermata, Brachiopoda, Cephalopoda, Tunicata, etc.

The many streams emptying into the Black and Caspian seas, make them fresher than the Atlantic Ocean. The faunas of these are typically marine, but practically all are dwarfed in size as compared with the same species in the Atlantic. For example, the following Black Sea species are considerably smaller in the Black Sea than in the British seas: Littorina rudis, Cerithium adversum, Trochus umbilicus, Murex erinaceus, Nassa reticulata, Cardium edule, Anomia ephippium, Venus gallina, Tellina tenuis, Mactra triangula, Solen ensis, Pholas candida, etc. ${ }^{1}$

The common European cockles, Cardium, are large, thick and rough shells, and thrive best under purely marine conditions. The species found growing in brack-

\footnotetext{
${ }^{1}$ Forbes, E. Nat. Hist. of European Seas, pp. 201 and 202.
} 
ish waters are smaller than those in normal sea water. Cardium edule is found in the British Isles in harbors and high up tidal rivers, where the water gets brackish; its shell is modified, invariably reduced in size, thin, and with less strongly marked external characters. The ten species of Cardium in the Caspian Sea are all aberrant forms, all related back to $C$. edule, small, thin and smooth, with lateral or central teeth or both suppressed. So likewise with the cockles of the Black and Baltic Seas; in the latter the salinity is reduced one half by the water from the rivers. ${ }^{2}$ The Greenland cockle lives in estuaries; it is no longer found in Europe but is very abundant in the Pliocene (Crag) of Suffolk and Norfolk, especially in the fluvio-marine portions. It is thin, smooth, almost edentulous, with rudiments of a single tooth in each valve in the young shells which finally disappear. ${ }^{3}$

Some forms, as Scrobicularia and Mactra solida, have become thoroughly adapted to a brackish water environment and attain their largest size there. But many, if not most species, which live in normal sea water and in brackish water are smaller in the latter, as is true of Cardium edule, Mya arenaria and Littorina littorea.

(b) Change due to a Concentration of Salt, Iron, etc.-When a body of water has become concentrated to a point where precipitation of its salt takes place, as is practically the case in the Great Salt Lake or entirely so in the Dead Sea, no life can exist in it. But from the normal sea water to this condition there takes place progressively a lessening both in the number of species and in the size of the individuals there present.

Many fossil dwarf faunas have been ascribed to this cause, as, for example, those of the Permian.

That even a comparatively slight concentration of the sea water may produce a dwarfing in its fauna appears to be indicated by the western Mediterranean species. Dana' gives the amount of saline matter in the Mediter-

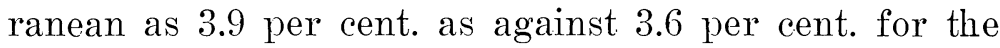

2 Dana. Manual of Geology, p. 121.

${ }^{3}$ Forbes, E. Loc. cit., pp. 211-215. 
Atlantic. ${ }^{4}$ De Lapparent ${ }^{5}$ states that this western portion has a few of the Atlantic species but all of reduced size. A comparison of British and Spanish coast species gives the same result. Haliotis tuberculatus ${ }^{6}$ is larger at Guernsey than on the Spanish coast. The difference of temperature between the two localities may be another factor in causing this dwarfing.

(c) Change due to an Increase of $\mathrm{H}_{2} \mathrm{~S}$. - The presence of much of this heavy gas in an enclosed or partially enclosed basin would prevent the presence of living organisms and hence the only fauna which sediments deposited here could contain, would be free-swimming or floating individuals. This pelagic fauna contains besides fish, pteropods, and especially larval forms of almost every animal group. Thus the sediment of such an enclosed basin would contain small shells, embryonic in character, pteropods and a few fish. Andrussow ${ }^{7}$ has shown that in consequence of the greater salinity and density of the deep water, the Black Sea shows only slight evidence of vertical currents. Such currents are apparent only to a depth of 125 fathoms, and hence only to this depth is there sufficient oxygen for the support of animal life. At a depth of 100 fathoms the separation of $\mathrm{H}_{2} \mathrm{~S}$ is observable, increasing in amount with the increase in depth. The separation of $\mathrm{H}_{2} \mathrm{~S}$ is regarded as due to the agency of microbes (Sulfobacteria) living upon animal remains of the free-swimming and floating forms of life sunk to the bottom. It is attributable in part also to the derivation from sulfates. Hand in hand with the separation and enrichment in $\mathrm{H}_{2} \mathrm{~S}$ is the diminution in sulfates in the sea water, the separation of the carbonates and of FeS. In the great depths of this sea the bottom is covered with black or dark blue mud in which are abundant remains of free-floating diatoms, fragments of quite young pelecypods, and minute grains of $\mathrm{CaCO}_{3}$, and much FeS.

${ }^{7}$ Clarke. N. Y. State Mus. Mem., 6, 200.

${ }^{4}$ Manual of Geology, 4th ed., p. 121.

${ }^{5}$ Traite de Geologie, 5th ed., 1, 132.

'Forbes. Loc. cit., p. 171. 
2. Influence of Mud and other Mechanical Impurities in the Water.-Though the western Mediterranean contains a dwarf fauna, yet it is the eastern part which is especially so characterized. This is attributed by de Lapparent ${ }^{8}$ to the presence in the water of the eastern basin of many very fine particles of solid matter (Nile sediment) which becomes deposited only very slowly. A similar cause apparently aided in dwarfing some of the faunas of the Windsor (Nova Scotia) Carboniferous, also those of the Cobleskill, Rondout, Manlius, Bertie, etc.

3. Influence of a Floating Habitat.-Forms which live attached to floating seaweed will tend to be small owing to the fact that the increased weight of the individual due to growth will cause its sinking with its attached seaweed before the attainment of large size. Hence only the smaller individuals would occur on the seaweed or in the sediment beneath. Fuchs has shown ${ }^{9}$ that in the eastern, shallower part of the harbor of Messina, the sea is now filled with different kinds of algæ, densely crowded together. This seaweed thicket swarms with small mollusks, seeking here food and protection. Here are species of Rissoa, Trochus, Turbonella, Columbella, Marginella, Cerithium, Cardium, Cardita, Lucina, Arca and Venus, but they are throughout of smaller size than normal. This dwarf fauna is thus not the result of stunted growth but is very probably due to the fact that the algæ can not support large and heavy shells. Such dwarfing and also thinning of shells fastened to seaweed (giant kelp) Arnold $^{10}$ notes in the case of Pecten latiauritus var. fucicolus of the California coast. This in its floating habitat far from shore is not subjected to the shock of the breakers, and hence the shell not only remains thin but also gradually loses its ribbed ornamentation. $P$. latianritus likewise grows attached to kelp but when near shore it is more strongly sculptured than when living in deeper and quieter waters.

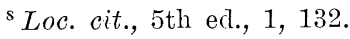

${ }^{9}$ Walther. Einleitung in die Geologie, p. 33.

${ }^{10}$ U. S. G. S. Prof. Paper 47, p. 131. 
The ability of mollusks to reproduce before the attainment of full size accounts for the perpetuity of such dwarfed species. Semper, in reference to oysters and fresh-water mussels, says on this point: ${ }^{11}$

"Where formerly really gigantic pond mussels were found, now only quite small ones occur; and it is well known that the European oysters are gradually becoming smaller. This results from the circumstance that both these mollusks are capable of reproduction while they are still quite small, and now never grow to their full size, because they are destroyed before they have accomplished their full growth."

A probable fossil example is the dwarf fauna of the Ohio Black shale.

4. Variations in Temperature.-The influence of temperature upon the size of the animal is well illustrated by an experiment of Semper: $:^{2}$

"I found by experiment that this animal (Limncea stagnalis) when young first begins to assimilate food, and consequently to grow, when the water is about $12^{\circ} \mathrm{C}$; at the same time a temperature much below has no injurious effects on the animal's life, though it entirely prevents its growth. .... Assuming that a young Limnæa were placed in a lake or stream of which the temperature constantly exceeds the minimum at which the snail ean begin to grow, during only two months of the year, while it never perhaps reaches the high optimum $25^{\circ}$, the mollusk will be unable to attain its due proportions during the first year, or to grow to its full size even during the second, and thus a dwarfed form will inevitably arise. This dwarfed form will still be able to reproduce and multiply itself, for the maturation of germinal matter-the ovum and the sperm-takes place during the winter and early spring, at a time when the low temperature of the water hinders all growth. The optimum of warmth for sexual processes is much lower than that for growth. Thus a permanently diminutive race might arise if the conditions of temperature above described remained constant for several succeeding years in the lake or streams in which the young mollusks or the egg's have been deposited."

But not only does too low a temperature produce dwarfing but when the temperate or polar species are introduced into water warmer than their optimum, they likewise become smaller. ${ }^{13}$

${ }^{11}$ Semper. Animal Life as affected by the Natural Conditions of Existence. D. Appleton and Co., 1881, p. 425.

${ }^{12}$ Loc. cit., pp. 108 and 109.

${ }^{13}$ Semper. Loc. cit., p. 118. 
Dall says :14 "As in mammals and birds so in Pectens the same species in the northern part of its range is larger than in the south unless its habitat is distinctly tropical." ${ }_{15}$ So too the slight excess of temperature, 3 " within the Mediterranean over that of the Atlantic in corresponding latitudes may help to cause the dwarf fauna within that basin.

Möbius mentions ${ }^{16}$ that the same mollusks living on the coast of Greenland and in the Baltic Sea are in the former very large and in the latter small and thin-shelled; this variation he attributes to the constant temperature in the former case and the very great extremes in the latter.

The dwarf faunas of the Black and Caspian Seas are doubtless partly due, according to Forbes ${ }^{17}$ to the great extremes in temperature which they experience between winter and summer.

5. Change due to Extremes in Depth of Water.-For each organism there are certain limits of depth of water in which it best flourishes; outside of these in either direction there naturally results a tendency towards pauperization.

(a) Very Shallow Pools.-Semper ${ }^{18}$ took specimens of Limnea stagnalis, hatched from the same mass of eggs, and placed them in aquaria containing different volumes of water. "All the animals were under equally favorable conditions" (as to food, temperature, gases, etc.) "irrespective only of the volume of water which fell to each animal's share; this varied at most between 100 and 2,000 c.c." The result showed that "the smaller the volume of water which fell to the share of each animal, the shorter the shell remained." The number of whorls was the same, four, but the average length of the shell in the 100 c.c. of water was $\frac{1}{4}$-inch, while in the 2,000 c.c. volume it was $\frac{3}{4}$-inch.

${ }^{1 *}$ Arnold. U. S. G. S. Professional Paper 47, p. 133.

${ }^{15}$ See also Weller, Pal. N. J., 4, p. 77.

${ }^{10}$ Semper. Loc. cit., p. 132.

${ }^{1 \tau}$ Loc. cit., p. 211.

${ }^{1 s}$ Loc. cit., p. 161. 
(These measurements were taken from the figures.)

(b) Great Depths. - The pauperization of faunas with increase in depth appears to be due primarily to the decrease in light, which is essential to plant growth, and thus indirectly to animal life. Secondarily it is due to the decrease in temperature, the increase in the heavier contents of the water, and the greater pressure with depth.

In Geneva Lake the deep fauna is small and sluggish while their surface representatives are larger and active.

In abyssal ocean faunas there are few mollusca, and these are small, translucent, and white, with few crabs and annelids, but many echinoderms and porifera. ${ }^{19}$

With decrease in size from higher to deeper regions there is further pauperization, evidenced in the loss of brilliant coloring and variety of pattern. In the Mediterranean the proportion of colored to uncolored shells at depths of 35 to 55 fathoms is 1 to 3 ; at 100 fathoms and over, it is 1 to $18 .^{20}$

The very many dwarf or depauperate fossil faunas already noted in the literature are doubtless but a small fraction of those still unnoted. The causes which are active at present in effecting this result were very probably equally active during each year of each era somewhere upon the earth's surface; so that the total number of such examples must be very great. Some of the fossil faunas, as for example, that of the Genesee, consist of uniformly small species, a selective agency having discarded the larger ones; here no stunting of growth is apparent. In such other faunas as that of the Pyrite bed of the Tully horizon, all of the individuals are smaller than the normal individuals of those species, thus showing very decidedly the stunting effect of environment. In still other cases, such as the Tertiary deposits at Steinheim, only a portion of the species were affected unfavorably by the environment, becoming dwarfed in size or of a bizarre shape, while the rest of the fauna were of the normal size for the species.

${ }^{19}$ Heilprin. Geographical Distribution, p. 262.

${ }^{20}$ Forbes. Loc. cit., p. 189. 
The following few dwarf faunas are described in illustration of the preceding agencies:

a. Faunas of the Cobleskill, Rondout, Manlius and Bertie of New York.

$b$. Faunas of the Pyrite bed of the Tully horizon and of the Clinton iron ore.

c. Fauna of the Genesee and Ohio shales; Styliolina limestone of New York.

d. Fauna of the Windsor (Nova Scotia) Carboniferous.

e. Faunas of the Permian.

f. Upper Cretaceous fauna of New Mexico and southern Colorado.

g. Tertiary lake fauna of Steinheim, Germany.

$h$. Pleistocene ? fauna of the lower Hudson River.

a. The Manlius, Rondout and Cobleskill formations of eastern New York, as well as the Bertie of the western part of the state are conspicuous for their dwarf faunas. The cause was probably in part the greater density of the water and in part the presence of lime mud, making the waters impure mechanically. The section of the rocks at Howes Cave is as follows : ${ }^{21}$

Coeymans, a typical lime sand rock (calcarenite).

Manlius, a fully laminated lime mud rock (calcilutite) with occasional beds of a lime sand.

Rondout, lithology as in Manlius but more argillaceous in upper portion.

Cobleskill (Coralline), lithology about the same as Manlius.

(Slight disconformity.)

Brayman (upper Salina), possibly the equivalent of the Bertie of western New York. Shales gray to green with traces of gypsum. Many iron nodules. ${ }^{22}$

(Great disconformity.)

Lorraine.

Deposition was probably continuous from the Cobleskill to the Coeymans, as there is no evidence of a stratigraphic

${ }^{21}$ Hartnagel. N. Y. State Mus. Bull. 69, p. 1114.

$2_{2}$ Grabaul. N. Y. State Mus. Bull. 69, p. 101. 
break. That some at least of these beds were deposited in shallow water and even exposed at times to the sun is shown by the presence of cross bedding, ripple marks, and mud cracks. As is usually the case, these faunas show more strongly their dwarfed condition when viewed as a whole than when distinct individuals are considered; for the reduction in size has not been very great in individual cases, but is shown slightly in nearly all of the forms. For example, Whitfieldella nucleolata is equally small in all three of the formations (Cobleskill, Rondout and Manlius) ; the Spirifers, likewise, are conspicuous for their small size, S. corallinensis and S. eriensis from the two lower horizons and S. vanuxemi from the Manlius. Favosites precedens is a small form of $F$. helderbergice found in the two lower horizons. The presence of a lime mud seems to indicate that the waters in which deposition took place was denser with alkalies than normal sea water, otherwise the mud would have gone into solution as is usually tlie case when limestone is eroded. Such abnormal conditions would have a dwarfing effect upon the individuals living there, as has been noted in the case of the Mediterranean. To this unfavorable influence would be added the mechanical impurities of the mud, for on account of the shallowness of the water, the mud would probably be kept by the waves in an almost constant state of suspension. The occurrence of these dwarf faunas between the periods of small exceedingly dense seas or lakes, depositing salt and gypsum, and the normal marine conditions of the Helderbergian is an additional proof of the greater-than-normal density of the water at that time.

b. An exceedingly interesting dwarf fauna is that of the Pyrite layer in western New York at the horizon of the Tully limestone, but where that stratum is otherwise missing. This fauna is very fully discussed by Professor F. B. Loomis. ${ }^{23}$

The layer is a more or less discontinuous deposit of pyrite, appearing as very broad lenses but not over 1 foot in thickness. It contains a fauna of not less than 45 ${ }^{23} \mathrm{~N}$. Y. State Mus. Bull. 69, 892-920. 
species, few of which, though adults, are over $2 \mathrm{~mm}$. in diameter. The fauna includes 1 blastoid, 15 brachiopods, 12 pelecypods, 6 gastropods, 2 pteropods, 7 cephalopods, 1 trilobite, and 2 ostracods. These have all, however, been dwarfed until their average size is only one fifteenth that of the same species in the preceding Hamilton. The cause of this dwarfing is suggested to be the presence of much iron in solution and the gases arising from the decaying vegetable and animal matter. "The iron in the water, as ferrous carbonate, was probably precipitated by the sulfuretted hydrogen" from the organic matter, and thus formed pyrite $\left(\mathrm{FeOCO}_{2}+\mathrm{H}_{2} \mathrm{~S}=\mathrm{FeS}+\mathrm{CO}_{2}+\right.$ $\left.\mathrm{H}_{2} \mathrm{O}\right) .{ }^{24}$

That iron in the water has a dwarfing effect was shown by experiments upon fishes and tadpoles ${ }^{25}$ which in eight months had been retarded in growth from three to five $\mathrm{mm}$. The same is apparently shown in the fauna of the oolitic iron ore of the Clinton beds; in these beds at Rochester, N. Y., the species have "an average of about one third the diameter of the same species in the beds just above and below.'?26

The same condition was noticed in similar beds in Kentucky.

The following list will give a general view of the average size of the dwarfed forms. Loomis gives the average measurement of each species.

Spirifer fimbriatus mut. pygmaus Loomis is shown to be one twenty-fifth the normal size of the species.

Nucleospira concinna mut. pygmaa Loomis is one fifteenth that of the species.

Tropidoleptus carinatus mut. pygmeus Loomis is one fifteenth.

Nucula lirata mut. pygmea Loomis averages one tenth the size of the normal species.

Paracyclas lirata mut. pygmea Loomis is only one twentieth.

${ }^{2 \pm}$ Loc. cit., p. 920.

${ }^{25}$ Loc. cit., p. 895.

${ }^{20}$ Loc. cit., p. 895. 
The same species of gastropods and cephalopods vary considerably in size, much more so than do the brachiopods.

Since "iron solution in water tends to settle gradually to the bottom, as was found in experimenting on the fishes ... it is not surprising to find that the brachiopods, which are either sessile or lie on the bottom, are the most dwarfed." ${ }_{2 \pi}$ The brachiopods are seldom one fifteenth the normal in size, nor do they vary much from this; while the gastropods and cephalopods, groups of greater freedom of motion often vary in the same species from one twenty-fifth to one half the normal size; those which evidently grew up in this iron water being much smaller than those which entered it when partly grown. "All of these fossils then represent cases of arrested development, with the understanding that the arrest is at no given point but all through the development." ${ }^{2 s}$ It is thus a case rather of retarded development or bradygenesis.

These retarded individuals appear like the young of earlier Devonian types.

c. From analogy with the Black Sea deposit, Clarke ${ }^{29}$ conceives that the black, very thinly and evenly laminated shales of the Genesee in western New York, with their dwarf invertebrate fauna and fish, with their abundant segregation of iron sulfide, limestone nodules, etc., are likewise the result of accumulation in waters of great depth and imperfect vertical circulation. Dr. Clarke notes the presence of surface ocean currents in this region. He thus interprets the Styliolina limestone, four to six inches thick, at the base of the Genesee in western New York, as essentially a pteropod ooze caused by the meeting of a cold northern current and a warm southern one bearing these pteropods. The cold current thus acted as a barrier to the northwest spread of these pteropods.

An accessory agent in the production of this dwarf

${ }^{-7}$ Loc. cit., 898.

${ }^{2 s}$ Loc. cit., p. 900.

${ }^{29}$ Loc. cit., p. 201. 
fauna of the Genesee may have been the presence of a sargasso sea as suggested years ago by Newberry for a similar fauna in the Ohio black shales. ${ }^{30}$ The Genesee and Ohio black shales, occurring from New York to Virginia and west to Kentucky and Indiana, contain throughout their whole extent some or all of the following small species: Lingula spatulata, L. ligea, Schizobolus concentricus, Chonetes scitulus, Leiorhynchus quadricostatus. These species are not only small, but also thin, the largest or last named being very frequently if not usually crushed through the pressure of the overlying sediment. This smallness and thinness apparently indicates a habitat for the living animals where they were not subjected to the shock of waves as are shore-living species.

d. At Windsor, Nova Scotia, a very fossiliferous limestone, of Carboniferous age, occurs between conglomerate, sandstone and a black shale of the same age below and coal measures of sandstone and coal above. The coal is seen in the Joggins region across the bay. The shallow water or terrestrial origin of the former set of beds is indicated by the predominance of the coarse clastic sediment, the presence of ripple marks, footprints and Lepidodendra. A similar origin accounts for the latter.

The fossils of these Carboniferous limestones show the effect of the unfavorable environment in which they lived at the time these limstones were being deposited. Brachiopods suffer most, being depauperate throughout the series, the pelecypods, though much dwarfed, suffer less diminution, while the cephalopods were the most resistant to the dwarfing agencies; $i$. e., the more closely a species was confined to a particular habitat the more dwarfed were the resultant adult forms.

The uniformly small size of most of the species is attributed by Dawson to two causes: ${ }^{31}$

1. Variation in depth and content of the water as

${ }^{30}$ Williams. U. S. G. S. Bull. 210, 110.

${ }^{31}$ Acad. Geol., p. 284. 
illustrated by one layer which is brown and impure, indicating deposition in shallow and turbid water. In this layer the brachiopods are especially small and depauperate. Productus corc rarely reaches one inch in diameter and the Rhynchonellas are minute. The pelecypods are very abundant but dwarfed.

2. The influence of the formation of the beds of gypsum and gypseous marls at the time these limestone reefs were growing. Dawson ascribes the formation of these gypsum deposits to chemical change produced on the calcareous beds and reefs by contact of streams charged with $\mathrm{H}_{2} \mathrm{SO}_{4}$. Such streams are easily accounted for by the volcanic activity known to have occurred in this region while the shell beds were growing. The great amount of $\mathrm{CO}_{2}$ released in the change from calcareous carbonate to gypsum would surely render unfavorable the water in which these limestone-secreting animals were living.

$e$. De Lapparent attributes the depauperized fauna of the Mediterranean in part to the greater preponderance of $\mathrm{CO}_{2}$ in the water of that sea over that of the Atlantic.

One of the most notable facts arising from a study of red strata is the very frequent total absence in them of all fossils and the often dwarfed and impoverished faunas of the associated strata of other colors. Such red beds are especially conspicuous in the rocks of the Devonian, Permian and Triassic eras. Geikie mentions that fossils are practically absent from the red strata of the Old Red sandstone of England, but abound in the gray or black. ${ }^{32}$

According to the same author" "the impoverished fauna of the Permian rocks of central Europe is found almost wholly in the limestone and brown shales, the red conglomerate and sandstone being, as a rule, devoid of organic contents."

In speaking of these same rocks de Lapparent ${ }^{3 t}$ says that "in northern Europe the mollusks of the upper

22 Textbook of Geol., 2, 1002.

${ }^{33}$ Loc. cit., p. 1066.

${ }^{3 \pm}$ Traite de Geologie, 5th ed., 1, 1017. 
Permian are always of small size as if they had lived in particularly unfavorable conditions." The cause he gives is that "there was formed a series of interior seas, soon dried up and where the excess of saltness had the effect of injuring the development of the mollusks. These seas have left here and there important deposits of salt and gypsum."

That this dwarfed fauna was not the normal, open-sea fauna of the Permian is noted by a comparison with the species of the Alps, the Mediterranean region, and India. While in northern Europe the predominating forms are pelecypods and brachiopods, with exceedingly few cephalopods, in these latter more normal regions, the cephalopods become very numerous and all are of a larger size. $^{35}$

It is interesting to note the resemblance of the fauna of the Carboniferous of Windsor, Nova Scotia, to that of the Permian of northern Europe. According to the determination of de Verneuil ${ }^{36}$ several species of brachiopods and pelecypods are common to the two regions, showing that similar conditions tend to bring about development along similar lines.

(In this connection Schuchert's discussion of the question-Is there a Permian system or only a Permian formation? - is enlightening.) ${ }^{37}$

$f$. The dwarf fauna of the Cretaceous strata of New Mexico and southern Colorado ${ }^{38}$ occurs in sandy shales and shaly sandstones, accompanied by innumerable fragments of wood. Cross bedding is frequent. The majority of the shells are of normal size, but with these occur many others which are distinctly smaller than in other regions. Lima utahensis Stanton is here only one half as large and Lucina subundata M. and $\mathrm{H}$. is also smaller than in Utah. Ostrea anomioides var. nanus Johnson is

${ }^{35}$ De Lapparent. Loc. cit., p. 1067.

${ }^{36}$ Davidson. Jour. of Geol. S'oc., 1863, p. 160.

${ }^{37}$ A. J. S., 22, 29-46 and 143-158, 1906.

ss Stanton. U. S. G. S. Bull. 106. Shimer and Blodgett. A. J. S., 25,67 . 
a dwarf form of the species $O$. anomioides Meek. Ostrea lugubris Conrad is a small species resembling the large O. blackii.

A probable explanation of this fauna and its habitat may be drawn from Metzger's observations ${ }^{39}$ upon that much-studied shell, Cardium edule. This upon the sand shoals of the ocean flats is small, while it attains its maximum size off the rugged coasts of Norway and Scotland. These Cretaceous strata with their sand, cross-bedding, much fragmentary wood, and a marine fauna indicate a shallow sea into which emptied some large river, a condjtion probably somewhat similar to that of the eastern part of the North Sea at present.

$g$. It often happens that while a portion of a certain fauna is dwarfed, the rest are of normal size. Hyatt ${ }^{1:}$ discusses an excellent example of this mixture of dwarf and normal forms from the Tertiary strata of Steinheim, northwestern Germany.

Into the Tertiary lake at. Steinheim migrated four varieties of Planorbis levis. The descendants of these are divided into the progressive series or those which became larger and more robust, and the retrogressive or those which became smaller, less robust and distorted.

The dwarfing of the one series may be explained as a sapping of the individual's energy due to its being in an unfavorable environment. It is common to note signs of old age appearing immediately after a severe injury to the animal. ${ }^{42}$

In gastropods this is often indicated by uncoiling and rounding of the whorls, so that these may be looked upon as signs of weakness in the animal. Hyatt discusses the reason for this as follows:

"Among living animals it is a matter of daily experience to find some races incapable of enduring variation in the surroundings to which others readily accommodate themselves and even thrive under." ${ }^{41}$

${ }^{39}$ Walther. Einl. in die Geol., p. 32.

${ }^{40}$ The Genesis of the Tertiary Species of Planorbis at Steinheim. Bos. Soc. Nat. Hist. Anniv. Mem., 1880.

${ }^{41}$ Hyatt. Loc. cit., p. 16.

${ }^{42}$ Shimer. Old Age in Brachiopoda. Am. Nat., 40, 115. 
"In the individual the effects are shown in the disturbance of the laws of growth, producing abnormal or premature weakness or in the natural exhaustion of the powers of growth causing senility. A wound and its results, whatever they may be, can unquestionably be so classified, since it is primarily a severe shock to the system which lays additional burdens upon the powers of growth and is usually followed if severe by retrogressive metamorphoses or premature old age . . . normal old age simply expresses the normal wearing out of the powers of vitalized tissue to sustain itself against the perpetual friction of existing physical surroundings. . . . When we compare these effects of unfavorable environment in producing distortion and decrease in size of the individual with the corresponding distortions and decrease in size of the retrogressive sub-series there is a certain similarity which learls to the supposition that the latter are also probably due to an unfarorable environment." ${ }^{* 3}$

h. At Storm King, about fifty miles above New York, was found in drilling a series of holes across the Hudson, an apparently dwarf fauna including only two species, Mulinia lateralis (Say), of which there are hundreds of specimens and Trivia trivittata Say, of which there are but few specimens in our collection.

(These fossils were obtained by Professor W. O. Crosby in February, 1908, and through his kindness these facts are presented.)

These were found in but one drill hole, though probably the same species are present in the others but passed unnoticed in the drilling. They occur 620 feet out in the river from the Storm King shore, 40 feet below the bed of the river, $i$. e., about 120 feet below the present river or sea level at that point. The Hudson is brackish at this point and as far north as Poughkeepsie, as is evidenced by the absence of ice houses below Poughkeepsie. Whether in the present bed of the stream there are any marine forms growing was not ascertained. The heavier sea water might still come up in sufficient amount to furnish a marine habitat even under quite fresh surface conditions. This dwarf fauna in the abundance of Mulinia lateralis suggests Pleistocene age.

These two species live at present off the New England

${ }^{43}$ Hyatt. Loc. cit., p. 15. 
and New Jersey coasts, in normal marine or but slightly freshened water. An average-sized fossil specimen of Trivia trivittat a is three eighth inch long with a greatest diameter of three sixteenth inch. An average size for those off the Massachusetts coast is two third inch by one third inch. The smaller specimen is less strongly ribbed and less nodose.

One of the larger of the fossil specimens of Mulinia lateralis measures five sixteenth inch by one fourth inch. The young shells off the coast are small, thin, with margins subequally rounded and beaks inconspicuous and nearly touching each other; this description applies to all of the Hudson River specimens. It does not seem probable, however, though possible, that so many shells could be gathered at random as was done by the drill without getting some adults. The more probable explanation seems to be that these fossil individuals were living in an unfavorable environment, a water less than normally saline, and through a consequent sapping of vitality, were not able to attain large size.

\section{Summary}

In the first part of the above discussion was given what appear to be some of the principal causes for the dwarfing of invertebrate water-living faunas; these were illustrated by present-day examples. In the second part a few fossil examples are described with a brief discussion of the probable cause of the dwarfing in each case.

The chief agency is apparently an abnormal habitat. A species, for generations used to an environment of sea water with a certain unvarying density, temperature, clearness and depth, would become so accustomed to that state of affairs that a change in one or more of the factors would affect it unfavorably. An unfavorable environment causes a greater expenditure of vitality in the continuance of life than does a favorable one. Hence after the maintenance of life itself, there would be less surplus energy left for g'rowth. There would thus result a 
tendency to smallness of size especially in those species having comparatively little vitality to start with. It could happen then that from this cause alone either all or but a few of the species of a fauna would become dwarfed.

The hard parts of the animal are so intimately related to the soft parts that whatever affects the soft parts is immediately impressed upon the building shell. Thus whatever ill or good conditions the animal is subjected to are expressed in the shell, as are moist and dry summers recorded by the annual rings of exogenous trees.

Two classes of dwarf faunas are noted: (1) Faunas where the individuals are of smaller size than that to which the species grows under normal conditions; this is the resultant of an abnormal habitat. (2) Faunas where all the individuals are small but of the normal size of the species; in this case some selective action has weeded out all the large and heavy species, leaving a dwarf but not stunted fauna. Dwarf faunas usually include representatives of both these classes.

Dwarfing shows itself in two ways:

1. An acquirement of old age characters by the dwarfed animal. Such old age characters as sluggishness, loss of external sculpture, teeth, etc., are very common in stunted forms.

2. A retention of youthful characters. That is, the animal's growth takes place so slowly, due to the abnormal environment that saps the vitality, that death overtakes it before it has passed through the youthful stage, and the animal develops no old age characters. 